\title{
MEMPERKUAT DAYA SAING GLOBAL PENGRAJIN BATIK DAN BORDIR KUDUS DENGAN UPAYA PENDAFTARAN HAK CIPTA
}

\author{
Sulistyowati, Kertati Sumekar, Sri Mulyani \\ Dosen Universitas Muria Kudus \\ sulistyowati@umk.ac.id
}

\begin{abstract}
ABSTRAK
Tujuan dari penelitian ini adalah, meningkatkan omzet penjualan dan kenaikan harga jual Pengrajin batik serta bordir melalui pendaftaran Hak Cipta menuju pemasaran global dengan beberapa fokus kegiatan, yaitu : (1) meningkatkan kemampuan sumber daya manusia dan merumuskan manajemen Pengrajin agar mempunyai peningkatan daya saing yang tinggi , (2) meningkatkan pemahaman dan kesadaran Pengrajin untuk mendaftarkan Hak Cipta, agar meningkatkan omzet dan harga penjualan produk , (3) memperluas akses pasar sampai ke pasar global .

Metode pendekatan yang dipakai adalah rantai nilai (value chain). Pendekatan ini secara sistematis memperhitungkan keseluruhan tahapan mulai dari proses produksi dan juga analisis dari berbagai keterkaitan dan aliran informasi sepanjang rantai. Strategi pengembangan didasarkan pada : (1) Pemetaan potensi sumber daya manusia dan komoditas unggulan yang dimiliki , untuk kemudian didaftarkan Hak Ciptanya,(2) Mendorong peningkatan peran Perguruan Tinggi, Pemerintah Daerah dan Pemerintah Pusat, Dinas dan Instansi Vertikal, perusahaan swasta, Badan Usaha Milik Daerah, Badan Usaha Milik Negara serta masyarakat untuk membangun ekonomi secara sinergis .

Hasil penelitian menghasilkan kesimpulan bahwa masih kurangnya kemampuan sumber daya manusia Pengrajin dalam meningkatkan daya saing yang tinggi, masih banyak Pengrajin yang belum memiliki pemahaman tentang pentingnya pendaftaran hak cipta dan Pengrajin belum mampu secara mandiri mengakses pasar global .

Keyword : batik, bordir, Hak Cipta, omzet, harga penjualan, global .
\end{abstract}

\begin{abstract}
The purpose of this research is to increase sales turnover and increase the selling price of batik and embroidery craftsmen by registering Copyright to global marketing with several focus activities, namely: (1) increasing the ability of human resources and formulating the Craftsman management in order to have increased competitiveness high, (2) increase the understanding and awareness of Craftsmen to register Copyright, in order to increase the turnover and price of product sales, (3) expand market access to global markets.

The approach method used is a value chain. This approach systematically takes into account all stages starting from the production process and also analysis of the various interrelationships and information flows along the chain. The development strategy is based on: (1) Mapping of potential human resources and superior commodities possessed, then the copyright is registered, (2) Encouraging the enhancement of the role of Higher Education, Regional Government and Central Government, Vertical Offices and Agencies, private companies, Business Entities Regional-Owned, State-Owned Enterprises and the community to build a synergistic economy.

The results of the study concluded that there is still a lack of human resource capabilities of Craftsmen in increasing their high competitiveness, there are still many Craftsmen who do not have a calm understanding of the importance of copyright registration and Craftsmen have not been able to independently access the global market.
\end{abstract}

Keyword : batik , embroidery, Copyright, turnover, sales prices, global . 


\section{PENDAHULUAN}

A. Latar Belakang :

Pemberdayaan Pengrajin batik, tenun dan bordir, di tengah arus globalisasi dan tingginya persaingan membuat Pengrajin harus mampu mengadapai tantangan global, seperti memahami tentang pentingnya pendaftaran Hak Kekayaan Intelektual guna mencapai naiknya omzet penjualan dan naiknya harga penjualan , meningkatkan inovasi produk dan jasa, pengembangan sumber daya manusia dan teknologi, serta perluasan area pemasaran. Hal ini perlu dilakukan untuk menambah nilai jual Pengrajin itu sendiri, utamanya agar dapat bersaing dengan produk-produk asing yang kian membanjiri di Indonesia, mengingat Pengrajin adalah sektor ekonomi yang mampu menyerap tenaga kerja terbesar di Indonesia ( Sudaryanto, 2011 ) .

Sejak tahun 1967 hingga 2004, perekonomian Indonesia mengalami perubahan struktur yang sangat signifikan. Peranan sektor industri terhadap PDB meningkat dari 7,3\% menjadi 28,1\%. Namun sejak 2004 hingga 2009, kontribusi sektor industri terhadap PDB semakin menunjukkan tren penurunan. Departemen Perindustrian melaporkan bahwa kontribusi sektor industri terhadap PDB terus menurun dari $28,1 \%$ menjadi $27,34 \%$. Tidak hanya itu, sektor industri semakin menunjukkan pertumbuhan minus. Melihat kenyataan ini, banyak pengamat ekonomi mengindikasikan terjadinya “ de - industrialisasi ".
De - industrialisasi salah satunya diawali oleh ACFTA . Dimulai dengan pembebasan 8626 pos tarif perdagangan antara Indonesia, China, dan 5 negara ASEAN lainnya di tahun 2004, kemudian secara bertahap terus dilakukan hingga puncaknya bertambah sebanyak 1696 pos tarif di tahun 2010 ( Sudaryanto , 2013 ) .

Kabupaten Jepara ( Indonesia ) memiliki Pengrajin Tenun Troso yang dalam keberadaannya sampai dengan saat ini perlu terus memperoleh pendampingan baik dari Pemerintah, Pemerintah Daerah maupun dari kalangan Perguruan Tinggi . Begitu juga Kabupaten Kudus ( Indonesia ), memiliki potensi pengembangan ekonomi yang besar , disamping terkenal dengan sebutan Kota Kretek, karena terdapat pabrik rokok terbesar di Indonesia yaitu Djarum dan wisata religinya yaitu Sunan Kudus yang identik dengan menara Kudus dan juga Sunan Muria . Kabupaten Kudus (Indonesia ) juga banyak terdapat sentra batik dan bordil milik Pengrajin dalam skala Usaha Menengah Kecil dan Mikro , yang unik dan menarik. Batik dan bordir tersebut dinamai batik dan bordir Kudus atau batik dan bordis Kudusan . Sejarah batik dan bordir Kudus (Indonesia ) dimulai pada era tahun 1935 dan berkembang pesat pada era 1970 - an .

Potensi produk Pengrajin Tenun Troso di Kabupaten Jepara (Indonesia) , dan Potensi produk Pengrajin Batik dan Bordir di Kabupaten Kudus 
(Indonesia ), belum seluruhnya paham tentang pentingnya pendaftaran Hak Cipta Batik, Bordir dan Tenun, sebagai suatu Hak Kekayaan Intelektual . Hak Cipta Batik, Bordir dan Tenun, sebagai suatu Hak Kekayaan Intelektual , akan memiliki pengaruh yang besar dan signifikan terhadap naiknya omzet penjualan dan naiknya harga penjualan , apabila produk yang didaftarkan Hak Ciptanya betul - betul memiliki nilai filosofis, eksklusif dan spesifik .

Di dalam sejarah tercatat bahwa pernah terjadi persaingan lokal yang sangat ketat antara pengusaha batik pribumi dengan pengusaha batik keturunan Tionghoa. Pada era 1980 - an Batik Kudus mengalami kemunduran karena sudah tidak ada pengrajin yang berproduksi lagi karena adanya perkembangan batik printing maka pengrajin batik Kudus banyak yang gulung tikar dan akhirnya masyarakat Kudus lebih senang bekerja sebagai buruh pabrik rokok karena banyaknya industri rokok di Kudus. Kondisi yang demikian membuat keadaan produksi Pengrajin Batik stagnan selama kurang lebih 20 ( dua puluh) tahun ( Batik Kudus , 2013 ) . Sekarang ini bergeliat lagi dengan tumbuhnya sentra sentra Pengrajin batik dan bordir di Kabupaten Kudus ( Indonesia ) berkat fasilitasi dan bimbingan serta binaan dari Institusi Perguruan Tinggi dan Pemerintah Daerah .

Kelemahan Para Pengrajin di sektor batik, bordir dan tenun adalah keterbatasan sumber daya manusia, baik sebagai tenaga pekerja untuk memproses dan menghasilkan produk serta kemampuan bersaing yang rendah karena keterbatasan kompetensi sumber daya manusia dan minimnya modal keuangan . Kondisi yang demikian tidak akan mampu diselesaikan dan diatasi sendiri oleh Pelaku dan Pengrajin. Pemerintah baik Pusat atau Daerah serta Institusi Perguran Tinggi harus saling bersinergi untuk secara kompak memperkuat Pengrajin agar dapat bersaing baik di dalam Negeri maupun di luar negeri guna menembus perdagangan dunia .

Salah satu cara untuk menembus pasar dunia, adalah dengan cara pameran produk baik secara on line ataupun dengan cara konvensional mengikuti langsung pameran produk batik, bordir dan tenun. Selain cara tersebut di atas, untuk menembus pasar perdagangan dunia adalah merebut kepercayaan konsumen dunia . Konsumen pasar dunia ternyata sebagian besar lebih memiliki minat membeli pada produk - produk yang sudah didaftarkan Hak Ciptanya, sebab Konsumen pasar dunia memiliki keyakinan bahwa produk yang sudah didaftarkan Hak Ciptanya memiliki kekhususan dan keistimewaan . Selain itu juga akan memiliki nilai filosofis yang tinggi, desain lebih spesifik dan eksklusif, sehingga merasa memiliki sesuatu yang berbeda dan unik .

Pengrajin di sektor batik, bordir dan tenun khususnya di Kabupaten Kudus ( Indonesia ) memiliki peranan 
penting dan strategis, khususnya ditinjau dari jumlah unit usahanya yang sampai dengan tahun 2018 mencapai 11.542 unit dengan daya serap setidaktidaknya sejumlah $69 \%$ dari tenaga kerja yang ada. Meskipun jumlahnya dominan dan cukup besar, namun peningkatan peranan terhadap perekonomian daerah relatif masih dinilai lambat. Kelambatan ini dapat terjadi karena omzet penjualan yang rendah dan margin keuntungan yang kecil ,yang disebabkan oleh harga penjualan yang masih rendah pula . Melalui penelitian ini, diharapkan Pengrajin di sektor batik, bordir dan tenun memiliki pemahaman dan kesadaran yang memadai untuk mendaftarkan Hak Ciptanya, guna meningkatkan omzet penjualan dan harga jual . Oleh karena itu sektor ini harus dimotivasi dan difasilitasi untuk mampu mengoptimalkan sumber daya yang ada, agar memiliki nilai tambah dan berdaya saing tinggi, sehingga dapat berperan dalam pertumbuhan dan percepatan ekonomi ke depan (Tambunan , 1999 ) .

Dari latar belakang tersebut , Peneliti mengambil peran ikut andil dalam pembangunan ekonomi kerakyatan , melakukan Penelitian dengan judul : Pendaftaran Hak Cipta Batik, Bordir Dan Tenun Serta Pengaruhnya Terhadap Peningkatan Omzet Penjualan Dan Naiknya Harga Jual Menuju Peningkatan Daya Saing Pengrajin Batik Indonesia Di Pemasaran Global .
B. Perumusan Masalah :

1. Bagaimanakah cara meningkatkan daya saing Pengrajin batik, bordir dan tenun dengan mendaftarkan Hak Cipta atas karyanya ?

2. Bagaimanakah strategi untuk menaikkan omzet penjualan dan menaikkan harga jual, terhadap produk Pengrajin di sektor batik, bordir dan tenun, yang sudah memiliki Hak Cipta?

3. Bagaimanakah strategi untuk menembus pemasaran global untuk produk Pengrajin di sektor batik, bordir dan tenun yang sudah memilik Hak Cipta?

C. Tujuan Penelitian :

1. Untuk meningkatkan daya saing UMKM batik, bordir dan tenun , dengan mendaftarkan Hak Cipta atas karyanya .

2. Untuk memberikan strategi cara menaikkan omzet penjualan dan menaikkan harga jual, terhadap produk UMKM di sektor batik, bordir dan tenun, yang sudah memilik Hak Cipta .

3. Untuk memberikan strategi guna menembus pemasaran global untuk produk UMKM di sektor batik, bordir dan tenun yang sudah memilik Hak Cipta .

D. Manfaat Praktis :

1. Dapat Meningkatkan daya saing UMKM di sektor batik, bordir dan tenun , dengan mendaftarkan Hak Cipta atas karyanya . 
2. Dapat memiliki strategi untuk menaikkan omzet penjualan dan menaikkan harga jual, terhadap produk UMKM di sektor batik, bordir dan tenun, yang sudah memilik Hak Cipta .

3. Dapat memiliki strategi untuk menembus pemasaran global untuk produk UMKM di sektor batik, tbordir dan enun yang sudah memilik Hak Cipta .

E. Metode Penelitian :

\section{Pendekatan :}

Pendekatan yang dipakai adalah rantai nilai (value chain). Rantai nilai merupakan sebuah rangkaian proses produktif mulai dari penyedia input produk, produksi, pemasaran dan distribusi hingga konsumen akhir. Pendekatan ini secara sistematis memperhitungkan keseluruhan tahapan mulai dari proses produksi dan juga analisis dari berbagai keterkaitan dan aliran informasi sepanjang rantai.

\section{Strategi :}

Strategi pengembangan didasarkan pada :

1) Potensi sumber daya komoditas unggulan yang dimiliki .

2) Mendorong peningkatan peran Perguruan Tinggi, Pemda, Dinas dan Instansi, perusahaan swasta, BUMD, BUMN serta masyarakat untuk membangun ekonomi secara sinergis .

\section{Sasaran}

Sasaran pengembangan klaster UMKM ini adalah;

1) Pengrajin batik dan bordir di Kabupaten Kudus serta Pengrajin tenun Troso Di Kabupaten Jepara .

2) Dinas Tenaga Kerja, Perindustrian, Koperasi, Usaha Kecil dan Menengah di Kabupaten Kudus dan Kabupaten Jepara sebagai Tim Fasilitator untuk pengembangan UMKM .

4. Pentahapan :

Prioritas fasilitasi akan dibagi dalam tiga tahapan :

1) Tahap $1:$ memetakan Pengrajin batik dan bordir di Kabupaten Kudus dan Pengrajin tenun Troso di Kabupaten Jepara , untuk menggali potensi SDM dan potensi produk unggulan yang dapat didaftarkan Hak Ciptanya .

2) Tahap 2 : Mengembangkan dan membangun networking dengan pihak-pihak terkait, baik dari mitra usaha (supplier, agen dan pemasar), pemerintah dan dinas terkait, maupun lembaga-lembaga keuangan dalam menunjang percepatan pendaftaran Hak Cipta .

3) Tahap 3 : Meningkatkan kualitas produk dan menghidupkan desain dan corak kearifan lokal serta mengembangkan pangsa pasar dengan orientasi ke pasar global. 


\section{Implementasi Kegiatan :}

\begin{tabular}{|c|c|c|c|}
\hline Tahun & Aktifitas & Sasaran & Target \\
\hline 2019 & $\begin{array}{l}\text { FGD pertama dengan stake } \\
\text { holder }\end{array}$ & $\begin{array}{l}\text { Para pengrajin batik dan } \\
\text { bordir Kabupaten Kudus }\end{array}$ & $\begin{array}{l}\text { Mendapatkan data tentang } \\
\text { kebutuhan riil dari Para } \\
\text { Pengrajin }\end{array}$ \\
\hline & $\begin{array}{l}\text { FGD kedua dengan stake } \\
\text { holder }\end{array}$ & $\begin{array}{l}\text { Para Pengrajin tenun } \\
\text { Troso Kabupaten Jepara }\end{array}$ & $\begin{array}{l}\text { Mendapatkan data tentang } \\
\text { kebutuhan riil dari Para } \\
\text { Pengrajin }\end{array}$ \\
\hline & $\begin{array}{l}\text { Mengembangkan dan } \\
\text { membangun jejaring untuk } \\
\text { perluasan pasar produksi } \\
\text { dalam rangka meningkatkan } \\
\text { omzet penjualan }\end{array}$ & \begin{tabular}{lr}
\multicolumn{3}{l}{ Para pengrajin batik dan } \\
bordir Kabupaten \\
Kudus dan Para \\
Pengrajin & tenun \\
Troso Kabupaten Jepara \\
\end{tabular} & $\begin{array}{l}\text { Terealisasinya pemahaman } \\
\text { tentang pentingnya } \\
\text { pendaftaran Hak Cipta } \\
\text { untuk batik , bordir dan } \\
\text { tenun }\end{array}$ \\
\hline & $\begin{array}{lr}\text { FGD ketiga } & \text { strategi } \\
\text { meningkatkan } & \text { omzet } \\
\text { penjualan } & \end{array}$ & \begin{tabular}{lr}
\multicolumn{3}{l}{ Para pengrajin batik dan } \\
bordir r Kabupaten \\
Kudus dan $r$ Para \\
Pengrajin & tenun \\
\multicolumn{2}{l}{ Troso Kabupaten Jepara }
\end{tabular} & $\begin{array}{l}\text { Terealisasinya kesadaran } \\
\text { pendaftaran Hak Cipta } \\
\text { untuk batik, bordir dan } \\
\text { tenun }\end{array}$ \\
\hline & $\begin{array}{l}\text { Pelatihan pendaftaran Hak } \\
\text { Cipta }\end{array}$ & \begin{tabular}{lrr}
\multicolumn{3}{l}{ Para pengrajin batik dan } \\
bordir & Kabupaten \\
Kudus dan & Para \\
Pengrajin & tenun & Troso \\
\multicolumn{4}{l}{ Kabupaten Jepara } &
\end{tabular} & $\begin{array}{l}\text { Para pengrajin dapat } \\
\text { melakukan pendaftaran } \\
\text { Hak Cipta }\end{array}$ \\
\hline & Pelatihan manajemen bisnis & $\begin{array}{lr}\text { Para Pengrajin tenun } \\
\text { Troso Kabupaten } \\
\text { Jepara }\end{array}$ & $\begin{array}{l}\text { Para pengrajin mampu } \\
\text { menjadi manajer yang baik } \\
\text { bagi usahanya }\end{array}$ \\
\hline & $\begin{array}{l}\text { Pelatihan pemantapan } \\
\text { strategi peningkatan harga } \\
\text { jual }\end{array}$ & $\begin{array}{l}\text { Para pengrajin batik dan } \\
\text { bordir Kabupaten Kudus } \\
\text { dan } \\
\text { Para Pengrajin tenun } \\
\text { Troso Kabupaten Jepara }\end{array}$ & $\begin{array}{lr}\text { Para Pengrajin } & \text { memilki } \\
\text { target tahunan } & \text { untuk } \\
\text { mendaftarkan } & \text { Hak } \\
\text { Ciptanya } & \end{array}$ \\
\hline & $\begin{array}{l}\text { Publikasi dan diseminasi } \\
\text { Akhir penelitian }\end{array}$ & Tim pelaksana & $\begin{array}{l}\text { Terpublikasikannya hasil } \\
\text { Penelitian }\end{array}$ \\
\hline
\end{tabular}

6. Indikator keberhasilan :

1) Memiliki kompetensi SDM yang memadai dan komoditas unggulan yang bisa menembus pasar global / eksport .

2) Adanya kesadaran dan pemahaman untuk mendaftarkan Hak Cipta batik , bordir dan tenun .

3) Adanya sistem pengembangan dan innovasi produk dengan karakteristik khusus, yang eksklusif dan spesifik serta memiliki nilai filosofis kearifan lokal .

4) Meningkatnya omzet penjualan dan naiknya harga penjualan terhadap produk - produk yang sudah didaftarkan Hak Ciptanya .

5) Mampu menjadi penggerak pembangunan perekonomian di sekitarnya 
1. Sejarah Batik Dan Bordir Kudus :

Batik merupakan karya budaya yang mewakili identitas Indonesia di kancah internasional. Dalam selembar kain batik, terpapar identitas budaya bangsa, serta sejarah suatu daerah atau kota. Bukan hanya satu atau dua jenis dan motif batik saja yang lahir dan berkembang, namun ada ribuan yang tersebar di berbagai daerah di Indonesia. Salah satunya yaitu batik Kudus yang didesain dengan motif unik dan menarik. Batik Kudus merupakan produk yang dihasilkan dari salah satu daerah yang merupakan pusat perkembangan agama Islam, serta memiliki pengaruh kuat dari budaya Cina. Hal tersebutlah yang menjadikan batik Kudus ini sebagai hasil karya multikultur.

Sejak masa Sunan Kudus, sekitar tahun 1600an hingga 1930an, Batik Kudus mengalami asimilasi dengan kebudayaan Cina. Sejarah mengungkapkan bahwa pengaruh budaya dari para pedagang Cina zaman dahulu yang mendatangkan para pembatik dari Pekalongan menciptakan batik peranakan dengan ciri khas batik Kudus. Batik Kudus juga menghasilkan batik-batik lainnya yang sangat dipengaruhi budaya Islam. Hal ini terpapar dari dalam batiknya yang didominasi dengan motif Arab. Warnawarnanya pun cenderung gelap, seperti hitam, dan biru tua. Walaupun secara historis batik Kudus sudah ada pada masa Sunan Kudus, namun mulai eksis pada tahun 1935, dan berkembang pesat pada tahun 1970-an. Corak dan motif batik Kudus sangat beragam, karena pada masa itu selain berasal dari penduduk asli setempat, para pengrajin batik Kudus juga berasal dari etnis Tionghoa.

Batik Kudus yang dibuat oleh pengrajin asli Kudus dipengaruhi oleh budaya sekitar dan coraknya juga dipengaruhi batik pesisiran. Motif yang dibuat mempunyai arti ataupun kegunaan, misalnya untuk acara akad nikah ada corak Kudusan seperti busana kelir, burung merak dan adapula motif yang bernafaskan budaya Islam atau motif Islamic Kaligrafi. Motif yang bernafaskan kaligrafi dipengaruhi oleh sejarah walisongo yang berada di Kudus yaitu Sunan Kudus (Syech Dja'far Shodiq) dan Sunan Muria (Raden Umar Said). Corak yang bernafaskan Islam ini timbul karena pengrajin batik banyak berkembang di sekitar wilayah Sunan Kudus atau dikenal dengan Kudus Kulon.

Pada tahun 1980-an Batik Kudus mengalami kemunduran karena sudah tidak ada pengrajin yang berproduksi lagi. Hal ini disebabkan adanya perkembangan batik printing. Maka pengrajin batik Kudus banyak yang gulung tikar dan akhirnya masyarakat Kudus lebih memilih bekerja sebagai buruh pabrik rokok karena banyaknya industri rokok di Kudus. Namun, saat ini beberapa pengrajin batik di Kudus mulai menggiatkan kembali usaha batik Kudus yang telah lama hilang. Batik Kudus telah menjadi saksi sejarah 
bahwa budaya Indonesia sarat dengan budaya tolernasi yang menjunjung tinggi nilai-nilai keragaman budaya. Sudah saatnya nilai-nilai yang terkandung dalam selembar batik kudus digaungkan kembali dalam memperkuat jati diri bangsa. ( Batik Kudus : Semangat Multikulturalisme Dalam Selembar Kain | Horizon Budaya 2017 )

Selain memiliki potensi penghasil batik, Kabupeten Kudus juga memiliki potensi kerajinan bordir . Bordir Kudus ada dan dikenal semenjak Indonesia belum merdeka . Perkembangan secara pesat ada di awal tahun 1970 - an dengan skala industri rumah tangga . Bordir Kudus awalnya berkembang di daerah Kudus Kulon, daerah trsebut dikenal sebagai basis orang kaya, pedagang sukses dan Pengusaha rokok .

Bordir Kudus memiliki sejarah perjalanan yang panjang sejak dahulu kala . Timbul tenggelam dan jatuh bangun Para Pengrajin bordir Kudus menjadi saksi sejarah untuk menapaki eksistensi bordir. Sampai dengan saat ini bordir Kudus tetap menunjukkan eksistensinya untuk ikut menopang perkembangan ekonomi masyarakat setempat .

Di desa Pedurenan , Kecamatan Gebog , pada saat ini terdata kurang lebih ada sekitar 109 ( seratus sembilan ) Pengrajin bordir , dengan kriteria $30 \%$ berskala besar dan $70 \%$ berskala kecil . Di desa Pedurenan juga terdapat sekitar 107 Pengrajin konveksi dengan skala besar, menengah dan kecil ( Data : Tahun 2017 Dari Dinas Koperasi ) .

Sebagai wujud keberpihakan Pemerintah Daerah Kabupaten Kudus untuk memfasilitasi dan mengembangkan Pengrajin sektor bordir di Kabupaten Kudus dan di desa Pedurenanan khususnya , pada tahun 2009 , Pemerintah Daerah melalui program dan kegiatan di 7 ( tujuh ) Satuan Kerja Perangkat Daerah telah memberikan dukungan dana sebesar 1,126 Milyar . Dana tersebut digunakan untuk penguatan permodalan dan juga digunakan untuk mewujudkan percepatan klaster bordir dan konveksi . Dana tersebut juga digunakan untuk pelatihan manajemen usaha , meningkatkan kualitas produk , meningkatan omzet penjualan , kreativitas desain produk dan untuk pendaftaran Hak Cipta ( Kompasscom : 2019 ) .

Sejak zaman Yunani Kuno yaitu abad 7 - 6 SM sudah mengenal bordir sebagai hiasan lukisan di vas bunga . Perjalanan dan perkembangan jaman , kemudian di Yunani bordir dipadukan dengan bahan kain untuk digunakan sebagai pakaian .

Seni bordir sebenarnya sudah menjadi milik dunia, hal ini karena dalam sejarah juga mencatat bahwa sejak jaman Mesir Kuno orang sudah mengenal seni bordir. Seni bordir adalah seni sulam - menyulam yang dapat diidentikkan dengan seni lukis yang dituangkan dalam media serat, benang dan kain . Seni bordir 
menggunakan media bantu jarum dan benang .

Di jaman Mesir Kuno bordir , hiasan di pusara orang meninggal juga menggunakan seni bordir . Hal ini sebagai indikasi bahwa bordir sudah dikenal oleh dunia berabad - abad lamanya . Orang Mesir juga menggunakan hiasan bordir untuk pakaian, kain pelapis kursi bahkan untuk tenda (Wikipedia : 2019 ) .

Seni bordir memiliki ciri khas tertentu di setiap daerah, seperti halnya di Indonesia selain bordir dikenal dari Kudus , juga dikenal bordir dari Tasikmalaya, Pekalongan, Bukittinggi ( Padang, Sumatra Barat ), Manado ( Sulawesi Utara . Di setiap negara bahkan memiliki keunikan tersendiri dalam menghasilkan seni bordir .

Pada tahun 330 Masehisampai dengan abad 15 di Byzantium hiasan bordir dipadukan dengan cantik dengan ornamen emas . Bordir sebagai karya seni kerajinan sebenarnya bisa dipadukan dengan batik dan tenun sebagai upaya innovasi produk guna menghasilkan karya yang unik , eksklusif serta spesifik .

2. Sejarah Tenun Troso Jepara :

Tenun Troso awalnya dikenal sejak tahun $800 \mathrm{M}$ yaitu zaman

Kerajaan Mataram Islam . Pada saat itu tenun Troso digunakan untuk pelengkap kebutuhan sandang. Pada saat itu tenun Troso berawal dari tenun gedog kemudian berkembang menjadi tenun ikat .

Tenun Troso adalah kain ikat yang ditenun dari helaian benang pakan atau benang lungsum yang sebelumnya diikat dan dicelupkan ke dalam zat pewarna alami . Alat tenun yang dipakai adalah alat tenun bukan mesin ( Wikipedia : 2018 ) .

Orang di Troso yang pertama kali menekuni kerajinan tenun adalah Mbah Senu dan Nyi Senu, yang kemudian dapat terus berkembang dari satu generasi ke generasi berikutnya . Pada jaman Kerajaan Mataram Islam kaintenun menjadi kain dengan nilai tinggi . Hal ini dikarenakan pada jaman itu kain tenun hanya dipakai untuk acara - acara khusus dan istimewa yaitu untuk menemui Ulama Besar yang disegani yaitu Mbah Datuk Gunardi Singorojo, yang saat itu sedang menyebarkan Agama Islam .

Awal dibuat tenun Troso memiliki 2 ( dua ) motif unggulan yang sempat mengalami jaman keemasan yaitu : Motif Lompong dan Motif Cemara . Motif lain kemudian lahir yaitu Motif Lurik dengan garis - garis polos . Jaman keemasan Motif Lompong , Cemara dan Lurik tidak bisa bertahan lama karena kesulitan bahan baku, sebab saat itu kondisi politik goncang dengan meletusnya Gerakan 30 September 1965 / G 30 S . PKI .

Berawal dari keruntuhan jaman keemasan tersebut, maka selanjutnya desain dan corak tenun Troso lebih berkembang dinamis . Pengrajin tidak lagi membuat tenun berdasarkan nilai nilai budaya lokal saja , tetapi lebih berfokus pada pesanan dengan mengutamakan aspek peningkatan omzet dan aspek perluasan pemasaran . 
Berdasrkan fakta tersebut dapat disimpulkan bahwa desain dan corak tenun Troso dalam perkembangannya lebih mengutamakan aspek dagang dari pada budaya (Astin Soekanto : 2018 ) .

Pengutamaan aspek dagang tersebut dapat dibuktikan bahwa saat ini Tenun Troso juga banyak memproduksi sejumlah pesanan motif tenun dengan corak dan desain etnik budaya Bali, NTT , NTB , Kalimantan , Flores , Sumba , Lombok, bahkan corak etnik budaya Sikka Maumere ( Word Press. Com .: 2018 ) .

Tenun Troso yang sampai dengan sekarang masih eksis dan terus berkembang, baik macam corak dan desainnya , ataupun jangkauan perluasan pangsa pasar serta peningkatan kualitas produksi . Perkembangan tersebut adalah murni dari inisiatif masyarakat Troso Kabupaten Jepara yang memiliki jiwa sebagai entrepreneurship . Jiwa sebagai entrepreneurship masyarakat di Kabupaten Jepara tidak hanya pada kerajinan tenun saja, melainkan juga pada krajinan rotan dan seni ukir ukiran .

3. Pentingnya Pendaftaran Hak Cipta

Batik , Bordir Dan Tenun :

Hak Cipta adalah merupakan salah satu dari Hak Kekayaan Intektual, yang diatur oleh Undang - Undang Republik Indonesia Nomor : 28 Tahun 2014 Tentang Hak Cipta . Hak Cipta adalah hak eksklusif Pencipta yag timbul secara otomatis berdasarkan prinsip deklaratif, setelah suatu ciptaan diwujudkan dalam bentuk nyata tanpa mengurangi pembatasan sesuai dengan ketentuan peratuan perundang undangan .

Hak Cipta merupakan salah satu bagian dari kekayaan intelektual yang memiliki ruang lingkup objek dilindungi paling luas, karena mencakup : Ilmu Pengetahuan, Seni dan sastra dan Program Komputer ( Penjelasan Umum Undang - Undang Nomor : 28 Tahun 2014 ) . Dari penjelasan tersebut dapat ditarik kesimpulan bahwa : karya cipta batik , bordir dan tenun adalah termasuk karya cipta di bidang seni yang dilindungi oleh Undang - Undang Hak Cipta .

Perkembangan ekonomi kreatif yang dilakukan oleh Pengrajin menjadi salah satu pertimbangan Pemerintah untuk melakukan pembaharuan Undang - Undang tentang Hak Cipta, agar dapat mampu bersaing dalam ekonomi global dan pemasaran internasional . Undang - Undang Hak Cipta yang baru ini , lebih memenuhi unsur perlindungan dan pengembangan ekonomi kreatif, sebagai wujud bentuk proteksi dan fasilitasi kebijakan Pemerintah, guna mendorong kuatnya daya saing Pelaku ekonomi kreatif dalam pemasaran produk secara global . Sektor ekonomi kreatif yang dimotori oleh Para Pengrajin ini terbukti bertahan eksis walau dunia diterpa krisis ekonomi dan keuangan. Di sisi lain Pemerintah juga mengharapkan bahwa ada kontribusi penerimaan negara di sektor pendaftaran Hak Cipta agar perekonomian negara lebih optimal ( 
Penjelasan Umum Undang - Undang Nomor : 28 Tahun 2014 ) .

Perlindungan Hak Cipta mencapai selama hidup Penciptanya ditambah 70 ( tujuh puluh ) tahun setelah Pencipta meninggal dunia. Hak ekonomi Para Pencipta dan / atau Pemilik Hak Terkait , termasuk membatasi pengalihan hak ekonomi dalam bentuk jual putus ( sold flat ).

Pengelola tempat perdagangan bertanggungjawab atas tempat penjualan dan / atau pelanggaran Hak Cipta dan / atau Hak Terkait di pusat tempat perbelanjaan yang dikelolanya . Ketentuan tersebut di atas, menunjukkan bahwa produk yang sudah didaftarkan Hak Ciptanya mendapatkan perlindungan hukum secara komprehensif, baik dari awal proses produksi sampai dengan pemasaran . Pengrajin sebagai Pelaku Bisnis perlu memahami pentingnya pendaftaran Hak Cipta atas hasil kreasi Ciptaannya .

Hak Cipta tergolong dalam bentuk benda bergerak tidak berwujud dapat dijadikan objek jaminan fidusia . Keistimewaan ini sebagai penghargaan sekaligus dorongan harga masyarakat memiliki pemahaman akan pentingnya mendaftarkan Hak Cipta selanjutnya melakukan pendaftaran Hak Cipta setiap hasil karya ciptanya .

Pencipta, Pemegang Hak Cipta dan Pemilik Hak Terkait menjadi Anggota Lembaga Manajemen Kolektif agar dapat menarik imbalan atau royalti , yang dibuat dalam hubungan dinas dan digunakan secara komersial .
Sengketa keperdataan di dalam Hak Cipta secara efekif akan dilakukan melalui proses mediasi di luar pengadilan atau mediasi di dalam proses peradilan, arbitrase , konsultasi , negosiasi , konsiliasi, dan perdamaian oleh Para Pihak yang bersengketa secara langsung .

Sengketa secara pidana di dalam Hak Cipta , diterapkan delik aduan bukan delik umum dengan demikian dimungkinkan dan memberi peluang Para Pihak yang bersengketa untuk menyelesaikan dengan Mediasi Penal atau Restorative Justice .

Berdasarkan semua penjelasan terkait dengan pendaftaran Hak Cipta tersebut di atas , maka mulai sekarang Para Pengrajin batik dan bordir di Kudus serta Pengrajin tenun Troso di Jepara , diharapkan segera memiliki kesadaran untuk mendaftarkan ciptaannya agar memperoleh perlindunganhukum dan mendapatkanefek ekonomi berupa kenaikan omzet penjualan , naiknyaharga penjualan bahkan dapat memperoleh royalti dari Lembaga Manajemen Kolektif .

4. Konsep Daya Saing :

Daya saing merupakan salah satu kriteria untuk menentukan keberhasilan dan pencapaian sebuah tujuan yang lebih baik oleh suatu negara dalam peningkatan pendapatan dan pertumbuhan ekonomi. Daya saing diidentifikasikan dengan masalah produktifitas, yakni dengan melihat tingkat output yang dihasilkan untuk setiap input yang digunakan. 
Meningkatnya produktifitas ini disebabkan oleh peningkatan jumlah input fisik modal dan tenaga kerja, peningkatan kualitas input yang digunakan dan peningkatan teknologi ( Abdullah, 2002 ) .

Tantangan utama dari pemberdayaan otonomi daerah adalah pemahaman akan potensi daya saing daerah. Dengan pemahaman yang akurat dan lengkap akan potensi daya saing yang dimiliki oleh daerahnya, suatu pemerintah daerah akan dapat dengan mudah menyusun suatu kebijakan yang benar-benar baik dan pada gilirannya akan menciptakan iklim yang kondusif bagi dunia usaha di daerah yang bersangkutan ( Abdullah , 2002 ) .

\section{Michael Porter ( 1990$)$} menyatakan bahwa konsep daya saing yang dapat diterapkan pada level nasional adalah "produktivitas" yang didefinisikannya sebagai nilai output yang dihasilkan oleh seorang tenaga kerja. Bank dunia menyatakan hal yang relatif sama di mana "daya saing mengacu kepada besaran serta laju perubahan nilai tambah perunit input yang dicapai oleh perusahaan". Akan tetapi, baik Bank Dunia, Porter, serta literatur-literatur lain mengenai daya saing nasional memandang bahwa daya saing tidak secara sempit mencakup hanya sebatas tingkat efisiensi suatu perusahaan. Daya saing mencakup aspek yang lebih luas, tidak berkutat hanya pada level mikro perusahaan, tetapi juga mencakup aspek diluar perusahaan seperti iklim berusaha yang jelas diluar kendali perusahaan .

World Economic Forum (WEF), suatu lembaga yang menerbitkan " Global Competitiveness Report " mendefenisikan daya saing nasional sebagai " kemampuan perekonomian nasional untuk mencapai pertumbuhan ekonomi yang tinggi dan berkelanjutan ". Fokusnya adalah pada kebijakankebijakan yang tepat, institusi-institusi yang sesuai, serta karakteristikkarakteristik ekonomi lain yang mendukung terwujudnya pertumbuhan ekonomi yang tinggi dan berkelanjutan ( Abdullah , 2002 ) .

Untuk tingkat wilayah konsep daya saing ekonomi dapat didefenisikan oleh Departemen Pedagangan dan Industri Inggris (UK-DTI) yang menerbitkan "Regional Competitiveness Indicators", serta Centre for Urban and Regional Studies (CURDS), Inggris, dengan publikasi "The Competitiveness Project: 1998 Regional Benchmarking Report". Daya saing daerah menurut defenisi yang dibuat UK-DTI ialah kemempuan suatu daerah dalam menghasilkan pendapatan dan kesempatan kerja yang tinggi dengan tetap terbuka terhadap persaingan domestik maupun internasional. Sedangkan pengertian konsep daya saing wilayah menurut CURDS ialah sebagai kemampuan sektor bisnis atau perusahaan pada suatu daerah dalam menghasilkan pendapatan yang tinggi serta tingkat kekayaan yang lebih merata untuk penduduknya ( Ritonga 2015 ) . 
5. Klaster Pengrajin :

Pertumbuhan Pengrajin mulai menjadi topik yang cukup hangat sejak munculnya tesis flexible specialization pada tahun 1980-an, yang didasari oleh pengalaman dari sentra-sentra Industri Skala Kecil dan Industri Skala Menengah di beberapa negara di Eropa Barat, khususnya Italia. Sebagai contoh pada tahun 1970-1980an, pada saat industri skala besar di Inggris, Jerman dan Italia mengalami stagnasi atau kelesuan, ternyata industri skala kecil (terkonsentrasi di lokasi tertentu membentuk sentra-sentra) yang membuat produk-produk tradisional mengalami pertumbuhan yang pesat dan bahkan mengembangkan pasar ekspor untuk barang-barang tersebut dan menyerap banyak tenaga kerja. Pengalaman ini menunjukkan bahwa industri kecil di sentra-sentra dapat berkembang lebih pesat, lebih fleksibel dalam menghadapi perubahan pasar, dan dapat meningkatkan produksinya daripada industri kecil secara individu di luar sentra. (Becattini, 1990; Tambunan, 1999) .

Pengalaman Taiwan, justru menunjukkan perekonomiannya dapat tumbuh pesat karena ditopang oleh sejumlah usaha kecil dan menengah yang disebut community based industri. Perkembangan industri di Taiwan yang sukses menembus pasar global, ternyata ditopang oleh kontribusi Pengrajin yang dinamik. Di Indonesia, walaupun belum sepesat pertumbuhan di Taiwan, Pengrajin ternyata juga telah membuktikan mempunyai peranan yang cukup penting terutama bila ditilik dari segi jumlah unit usaha dan tenaga kerja yang diserapnya. Pengrajin di Indonesia sebagai katub pengaman pengangguran dan memiliki fungsi pemerataan pendapatan serta mengurangi angka kemiskinan. (Hill, H., 2001) . Berdasarkan dari pengalamanpengalaman di atas, maka pola pembinaan Pengrajin sesuai perubahan yang terjadi secara makro, paradigma yang berkembang tentang peran dan fungsi Pengrajin serta sebagai strategi pembinaan yang efektif, pendekatan kelompok dan kewilayahan ( berbasis klaster ) sangat sesuai .

Pendekatan klaster model Porter merupakan pengembangan dari industrial district atau kawasan industri yang dikembangkan oleh Alfred Marshall pada 1920 ( Desrochers dan Sautet , 2004 ) . Berbeda dengan Marshall yang hanya fokus pada perusahaan-perusahaan sejenis, klaster model Porter tidak membatasi hanya pada satu industri , tetapi lebih luas lagi - Diamond cluster model, meliputi industri - industri terkait ,dan perusahaan-perusahaan lain yang mempunyai keterkaitan dalam teknologi serta input yang sama. Menerapkan bekerja sama dalam satu klaster, maka perusahaan / industri terkait akan memperoleh manfaat sinergi dan efisiensi yang tinggi dibandingkan bekerja sendiri - sendiri ( Michael Porter, 2002 ) .

7.Penelitian Terdahulu :

1) Penelitian yang dilakukan oleh Mamik Indaryani dan Kertati dalam 
skim MP3EI tahun 2015 - 2016 dengan judul; " Pengembangan Usaha Menengah Kecil Micro Kain Tenun Ikat Troso JeparaSebagai Komoditas Unggulan Khas Daerah Menggunakan Pendekatan Diamond Cluster Berbasis Koperasi Menuju Pemasaran Global" ( Mamik , 2016 ). Tujuan dari kegiatan ini adalah menjadikan desa Troso kecamatan Pecangaan kabupaten Jepara sebagai prototipe desa produktif sebagai pilot project desa produktif sentra kerajinan kain tenun ikat yang menerapkan manajemen klaster berbasis koperasi. Dalam kegiatan tersebut telah berhasil dibentuk sebuah koperasi yang mewadahi para pengrajin tenun yang bernama "Koperasi Paguyuban Tenun Troso ". Saat ini desa Troso menjadi salah satu desa atraksi budaya, khsusnya atraksi tenun dan pameran hasil produknya dalam bentuk acara carnival sebagai salah satu acara tahunan warga desa. Link yang sudah terbangun adalah dengan pemerintah daerah, provinsi .

2) Penelitian yang dilakukan oleh Sulistyowati , Kertati Sumekar dan Sri Mulyani tahun 2018 Skim PSN dengan judul : “Peningkatan Daya Saing Pengrajin Batik Kudus Dengan Menghidupkan Desain Dan Corak Kearifan Lokal Menuju Pemasaran Global " ( Sulistyowati , 2018 ) .Tujuan dari penelitan ini adalah meningkatkan daya saing Pengrajin batik Kudus dengan menghidupkan desain dan corak kearifan lokal sebagai upaya menembus pemasaran global . Fokus kegiatannya adalah mendampingi , memfasilitasi dan melakukan pembinaan untuk meningkatkan simber daya manusia, memperbarui manajemen Pengrajin, mengangkat desain dan corak lokal serta memperluas akses pasar sampai menembus pasar eksport .

3) Penelitian yang dilakukan oleh Kertati Sumekar dalam skim Strategi Nasional 2015-2016 dengan judul: "Pengembangan Desa Produktif Sentra Bordir Dan Konveksi Sebagai Komoditas Unggulan Daerah Berbasis Klaster Dan Koperasi Menuju Pemasaran Global" ( Kertati , 2016 ). Tujuan kegiatan ini adalah mengembangkan Pengrajin bordir dan konveksi yang berada di desa Karangmalang Kudus , tujuan tersebut merupakan penjabaran dari apa yang tertuang dalam Rencana Strategis Kementerian Koperasi Dan Usaha Kecil Dan Menengah Tahun 2011- 2015 yang fokus pada lima hal , yaitu : (1) peningkatan iklim usaha yang kondusif bagi Koperasi dan Pengrajin (2) peningkatan akses terhadap sumber daya produktif , (3) pengembangan produk dan pemasaran bagi Koperasi peningkatan daya saing sumber daya manusia dan Koperasi penguatan kelembagaan Koperasi . Hasil dari kegiatan tersebut adalah, desa produktif sentra bordir dan konveksi yang telah membentuk 
klaster bordir dan mendirikan koperasi sebagai pusat perekonomian para pengrajin dalam klaster yang terbentuk .

4) Penelitian yang dilakukan oleh Sumintarsih dengan judul; "Pelestarian Batik Dan Ekonomi Kreatif' (Sumintarsih, 2019). Penelitian ini menyoroti tentang batik yang merupakan karya budaya bangsa Indonesia yang merefleksikan sebuah produk seni yang memiliki estetika, filosofi yang tinggi. Dalam perjalanan sejarahnya merekonstruksikan sebuah dinamisasi sebuah tradisi yang secara fungsional membalut kehidupan masyarakat pemilik budaya batik. Kekuatan daya kreativitasnya perlu diupayakan pelestariannya dengan berbasis pada pemanfaatan untuk menuju ekonomi kreatif. Eksistensi batik dalam wacana ekonomi kreatif akan berimplikasi pada terbangunnya kemampuan daya saing yang akan memberikan nilai tambah untuk kesejahteraan masyarakat ( Jurnal Jantra Vol. IV, No. 8, Desember 2009 )

Gambar road map penelitian seperti diperlihatkan pada gambar di bawah :

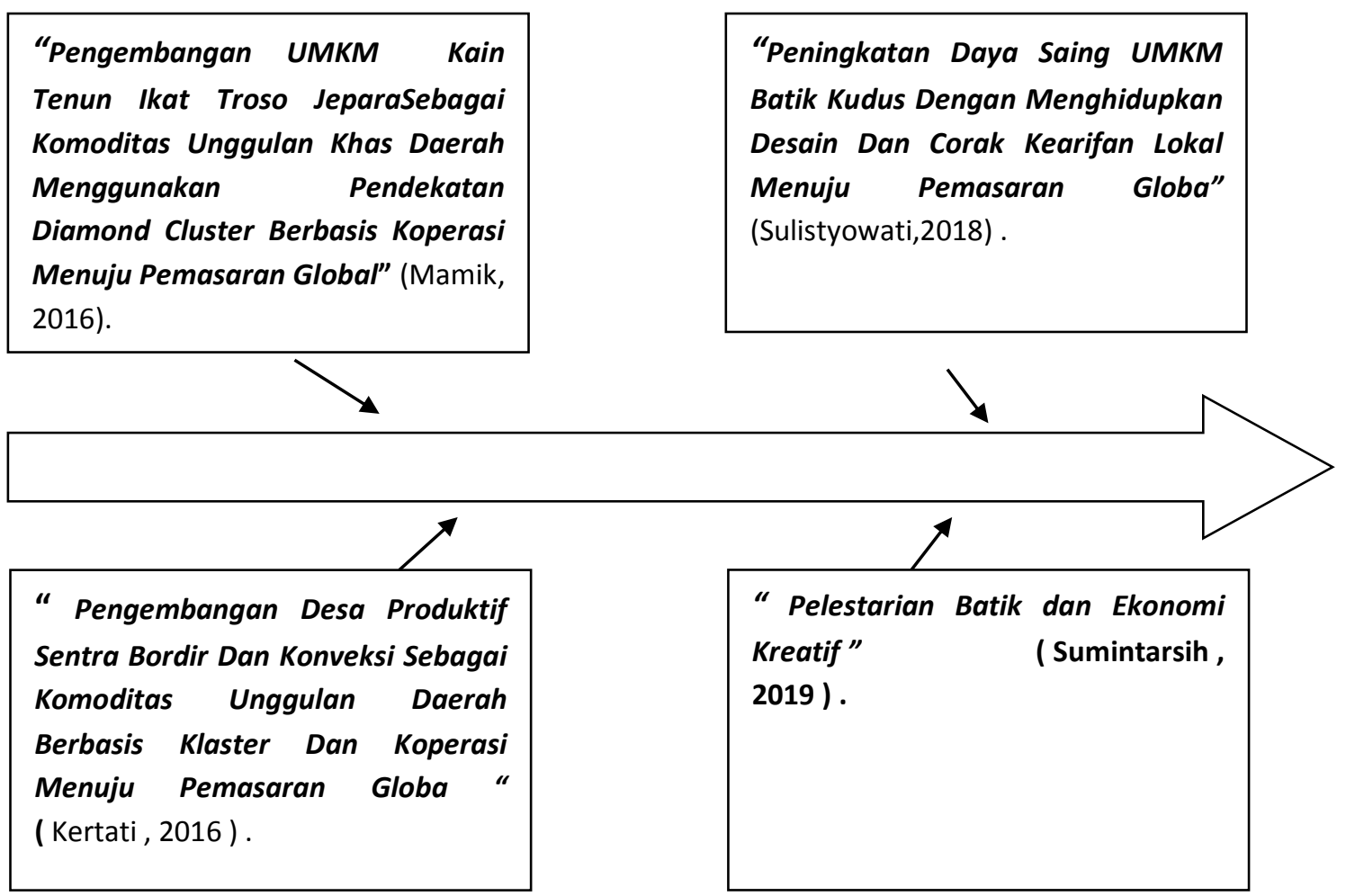


F. Pembahasan :

1. Cara meningkatkan daya saing Pengrajin batik, bordir dan tenun dengan mendaftarkan Hak Cipta atas karyanya :

Hasil dari penelitian yang sudah dilakukan, bahwa salah satu upaya peningkatan daya saing Pengrajin batik, bordir dan tenun, adalah dengan mendaftarkan Hak Cipta terhadap hasil karyanya . Pendaftaran Hak Cipta ini ternyata tidak bisa dilakukan secara individu dan secara sendiri - sendiri, baik melalui pendaftaran konvensional / manual melalui Kantor Wilayah Kementerian Hukum Dan Hak Asasi Manusia, yang membidangi tentang Hak Kekayaan Intelektual ataupun yang melalui sistem on line. Kesulitan ini disebabkan oleh adanya keterbatasan kemampuan sumber daya manusia dari Para Pengrajin . Para Pengrajin yang rata - rata hanya berpendidikan rendah dan menengah memiliki keterbatasan dalam hal menerapkan dan menggunakan sistem aplikasi pendaftaran Hak Cipta secara on line .

Selain karena keterbatasan sumber daya manusia dari Para Pengrajin , pendaftaran Hak Cipta juga mengalami masalah pada sektor pembiayaan. Hal ini dapat dipahami karena Para Pengrajin ini adalah berada pada posisi usaha kecil dan menengah bahkan usaha mikro .
Pendaftaran Hak Cipta batik, bordir dan tenun , untuk karya satu desain kurang lebih menghabiskan biaya Rp. 600.000,00 ( enam ratus ribu rupiah ) . Biaya sebesar tersebut bagi Pengrajin dengan kategori usaha kecil dan menengah bahkan usaha mikro dirasakan sangat berat .

Dua hambatan dalam pendaftaran Hak Cipta tersebut, harus dicarikan solusi dan diberikan fasilitasi serta dukungan , baik dukungan yang bersifat pengembangan sumber daya manusia maupun dukungan fasilitasi pendaftaran Hak Cipta .

Dukungan untuk pengembangan sumber daya manusia, dilakukan dengan cara membentuk Forum Grup Diskusi . Forum Grup Diskusi ini merupakan salah satu cara yang ditempuh untuk meningkatkan sumber daya manusia dari Para Pengrajin batik, bordir dan tenun. Kegiatan Forum Grup Diskusi, melibatkan semua Pengrajin batik, bordir dan tenun, berjumlah kurang lebih 60 Pengrajin, yang dilaksanakan pada hari Selasa tanggal 17 April 2019 , di rumah produksi batik Ibu Ummu Asiyati, di Kabupaten Kudus .

Peneliti bersama tim , masing masing menyampaikan paparan materi dengan tiga tema yang berbeda namun saling terkait yaitu tentang “ PENTINGNYA MEMAHAMI DAN MENDAFTARKAN HAK 
CIPTA , BAGI PARA PENGRAJIN BATIK , BORDIR DAN TENUN “ dan materi tentang " PENINGKATAN DAYA SAING PARA PENGRAJIN BATIK, BORDIR DAN TENUN MELALUI PENDAFTARAN HAK CIPTA “ serta materi tentang “ PENDAFTARAN HAK CIPTA SEBAGAI UPAYA PENINGKATAN OMZET PENJUALAN DAN PENINGKATAN HARGA PENJUALAN “ .

Pelaksanaan Forum Grup Diskusi yang bertujuan untuk meningkatkan kemampuan sumber daya manusia dari Para Pengrajin batik, bordir dan tenun ini, tidak hanya dilakukan sekali , tetapi dilakukan sebanyak empat kali, dengan pendalaman materi dan perluasan materi dari tiga tema yang sudah disampaikan pada pelaksanaan Forum Grup Diskusi yang pertama .

Pengulangan pelaksanaan Forum Grup Diskusi sebanyak empat kali ini , dimaksudkan sebagai upaya untuk memberikan pendidikan singkat untuk menaikkan kemampuan sumber daya manusia dari Para Pengrajin batik, bordir dan tenun . Tujuan akhir yang diharapkan adalah setelah selesai mengikuti empat kali Forum Grup Diskusi maka Para Pengrajin batik, bordir dan tenun, sudah memiliki pengetahuan praktis dan kemampuan riil tentang seluk - beluk Hak Cipta .
Pengetahuan praktis dan kemampuan riil tentang seluk - beluk Hak Cipta ini , meliputi : apa itu Hak Cipta , perlindungan Hak Cipta, jenis - jenis Hak Cipta , Indonesia sebagai Anggota dari berbagai perjanjian internasional di bidang Hak Cipta, kompetisi internasional di bidang Hak Cipta , Pemegang Hak Cipta dan Pemilik Hak Cipta, pengumuman HakCipta , Kuasa dan Konsultan Hak Cipta , Lisensi dalam Hak Cipta, Royalti Hak Cipta , Lembaga Manajemen Kolektif , Pembajakan Hak Cipta , penggunaan secara komersial Hak Cipta dan penerapan ganti rugi terhadap Pelaku pelanggaran Hak Cipta .

Dari akhir pelaksanaan selama empat kali yang sudah dilakukan dalam Forum Grup Diskusi ini secara nyata Para Pengrajin batik, bordir dan tenun, sudah memahami pentingnya pendaftaran Hak Cipta untuk karyanya yang berupa batik, bordir dan tenun . Pendaftaran ini penting dan dapat menaikkan daya saing produk Para Pengrajin batik, bordir dan tenun, baik pada pemasaran nasional maupun pemasaran global di tingkat internasional . Namun demikian, walaupun pemahamnan tentang pentingnya pendaftaran Hak Cipta batik, bordir dan tenun sudah ada pada diri Para Pengrajin serta keinginan untuk mendaftarkan Hak Cipta seluruh karyanya juga tinggi , 
tetapi ternyata Para Pengrajin batik, bordir dan tenun memiliki hambatan dan permasalahan baru yaitu terbentur dengan keterbatasan kemampuan keuangan untuk membayar biaya pendaftran Hak Cipta batik, bordir dan tenun. Biaya pendaftaran satu karya cipta batik, bordir dan tenun kira - kira menghabiskan biaya kurang lebih Rp.600.000,00 (enam ratus ribu rupiah) .

Untuk mengatasi persoalan keterbatasan kemampuan keuangan Para Pengrajin batik, bordir dan tenun , maka Peneliti bersama Tim memberikan bantuan berupa pendanaan gratis untuk pendaftaran Hak Cipta baik berupa karya cipta di bidang batik, bordir dan tenun. Agar fasilitasi berupa bantuan pendanaan gratis untuk pendaftaran Hak Cipta di bidang batik, bordir dan tenun, terealisasi secara merata agar adil, maka untuk setiap Pengrajin batik, bordir dan tenun, mendapatkan fasilitas pendaftaran satu karya baik karya batik, bordir dan tenun .

Dana yang digunakan untuk memfasilitasi pendaftaran gratis Hak Cipta ini diperoleh Peneliti dari Dana Hibah Kementerian Riset, Teknologi
Dan pendidikan Tinggi Indonesia . Pendaftaran Hak Cipta secara gratis ini, sebenarnya dimaksudkan Peneliti hanya sebagai pemicu dan pendorong agar Para Pengrajin batik, bordir dan tenun, untuk selanjutnya mau dan mampu mendaftarkan dengan biaya sendiri karya ciptanya sebagai Hak Cipta yang dilindungi oleh Undang - Undang Hak Cipta . Hal ini dimaksudkan apabila terjadi pembajakan karya cipta dari Para Pengrajin batik, bordir dan tenun, maka Mereka memperoleh perlindungan hukum dan dapat memperoleh ganti rugi .

Hasil dari perkembangan penelitian ini ternyata dalam rentang waktu satu tahun yaitu antara bulan April 2018 sampai dengan bulan Mei 2019 , setelah fasilitasi gratis pendaftaran Hak Cipta Para Pengrajin batik , bordir dan tenun, terbukti akhirnya Para Pengrajin paham dan mau secara mandiri untuk mendaftarkan karya ciptanya dengan biaya sendiri . Berikut ini adalah data dari jumlah Pengrajin Para Pengrajin batik, bordir dan tenun di Kabupaten Kudus dan Jepara , serta jumlah Hak Cipta yang sudah didaftarkan .

Tabel : 1 : Pendaftaran Hak Cipta Dalam Kurun Waktu April 2018 - Mei 2019.

\begin{tabular}{|l|l|l|l|l|c|}
\hline No & Jenis Pengrajin & $\begin{array}{l}\text { Jumlah } \\
\text { Pengrajin }\end{array}$ & $\begin{array}{l}\text { Jumlah } \\
\text { Karya Cipta }\end{array}$ & $\begin{array}{l}\text { Yang Sudah } \\
\text { Didaftarkan }\end{array}$ & $\begin{array}{l}\text { Yang Belum } \\
\text { Didaftarkan }\end{array}$ \\
\hline 1. & Batik & 2 & 87 & 36 & 51 \\
\hline 2. & Bordir & 23 & 679 & 48 & 631 \\
\hline 3. & Tenun & 49 & 2.045 & 498 & 1.547 \\
\hline & Total & $\mathbf{7 4}$ & $\mathbf{2 . 8 1 1}$ & $\mathbf{5 8 2}$ & $\mathbf{2 . 2 2 9}$ \\
\hline
\end{tabular}


Dari data tersebut di atas, dapat dicermati dan dianalisis bahwa jumlah keseluruhan Pengrajin batik, bordir dan tenun yang menjadi sasaran Penelitian ini adalah sebanyak 74 , semula Peneliti memberikan fasilitasi gratis setiap satu Pengrajin batik, bordir dan tenun, mendapatkan fasilitas satu pendaftaran Hak Cipta gratis . Jadi semula pada kurun waktu bulan April 2018 baru ada sekitar 74 Hak Cipta batik, bordir dan tenun . Namun dalam data tabel : 1 di atas , menunjukkan perkembangan angka pendaftaran Hak Cipta batik , bordir dan tenun pada kurun waktu antara bulan April 2018 sampai dengan bulan Mei 2019 sudah mencapai 582 Hak Cipta , dari total keseluruhan 2.811 karya cipta batik, bordir dan tenun . Dari data tabel : 1 di atas, tampak bahwa masih ada 2.229 karya cipta batik, bordir dan tenun yang belum didaftarkan Hak Ciptanya . Angkanya cukup besar dan hal ini menjadi kekhawatiran terjadi pembajakan karya cipta batik, bordir dan tenun milik Pengrajin .

Belum terdaftarnya karya cipta Pengrajin batik, bordir dan tenun , sebanyak 2.229 tersebut di atas, karena angkanya cukup besar harus menjadi perhatian Pemerintah Kabupaten Kudus dan Kabupaten Jepara untuk memfasilitasi pendaftaran Hak Cipta batik, bordir dan tenun secara gratis , melalui kebijakan penganggaran pada Anggaran Pendapatan Dan Belanja Daerah . Apabila hal ini terwujud, maka merupakan bukti nyata dukungan dan perhatian Pemerintah Daerah kepada Para Pengrajin batik, bordir dan tenun .

2. Strategi untuk menaikkan omzet penjualan dan menaikkan harga jual, terhadap produk Pengrajin di sektor batik, bordir dan tenun, yang sudah memiliki Hak Cipta :

Strategi yang Peneliti lakukan untuk membantu menaikkan omzet penjualan dan menaikkan harga jual, terhadadap produk Pengrajin batik, bordir dan tenun, yang sudah memiliki Hak Cipta , Strategiyang pertama adalah : dengan melakukan sosialisasi dan penyuluhan serta pendidikan kepada Konsumen tentang pentingnya membeli karya cipta batik, bordir dan tenun yang sudah terdaftar Hak Ciptanya . Srtategi kedua ialah : memberikan sosialisasi dan penyuluhan serta pendidikan kepada konsumen untuk sadar akan pentingnya menghargai karya cipta batik, bordir dan tenun yang sudah memilik Hak Cipta .

Sosialisasi dan penyuluhan serta pendidikan kepada konsumen dilakukan pada hari Selasa, tanggal 24 Juli 2018 , bertempat di rumah produksi 
batik milik Ibu Ummu Asiayati . Peneliti hanya mengundang Para Konsumen batik, bordir dan tenun, yang dianggap sebagai Pelanggan loyal sebanyak 45 orang. Dari 45 orang Pelanggan loyal tersebut diharapkan akan menjadi Pemicu dan Pelopor gerakan menghargai karya cipta batik , bordir dan tenun yang sudah didaftarkan Hak Ciptanya .

Hasil akhir yang diharapkan dapat tercapai setelah dilakukan sosialisasi dan penyuluhan serta pendidikan kepada konsumen batik, bordir dan tenun tentang Hak Cipta batik, bordir dan tenun, adalah adanya perbuatan nyata terhadap penghargaan karya cipta batik, bordir dan tenun, sehingga mampu mewujudkan tercapainya kenaikan harga dan omzet penjualan batik, bordir dan tenun milik Para Pengrajin . Berikut adalah data dari perkembangan kenaikan harga jual dan kenaikan omzet penjualan dari Para Pengrajin batik, bordir dan tenun, dalam kurun waktu April 2018 - Mei 2019 , sebelum dan setelah dilakukan sosialisasi dan penyuluhan serta pendidikan kepada konsumen / Pelanggan loyal

karya cipta batik, bordir dan tenun .

Tabel : 2 : Kenaikan Harga Jual Dalam Kurun Waktu April 2018 - Mei 2019.

\begin{tabular}{|c|l|l|l|l|c|}
\hline Nomor & $\begin{array}{l}\text { Jenis } \\
\text { Pengrajin }\end{array}$ & $\begin{array}{l}\text { Harga Jual / } \\
\text { Potong Sebelum } \\
\text { Didaftarkan Hak } \\
\text { Cipta }\end{array}$ & $\begin{array}{l}\text { Harga Jual / } \\
\text { Potong Setelah } \\
\text { Didaftarkan } \\
\text { Hak Cipta }\end{array}$ & $\begin{array}{l}\text { Jumlah } \\
\text { kenaikan }\end{array}$ & $\begin{array}{c}\text { Prosentase } \\
\text { Kenaikan }\end{array}$ \\
\hline 1. & Batik & Rp.200.000 & Rp.250.000 & Rp. 50.000 & $25 \%$ \\
\hline 2. & Bordir & Rp.400.000 & Rp.600.000 & Rp.200.000 & $50 \%$ \\
\hline 3. & Tenun & Rp.250.000 & Rp.300.000 & Rp.50.000 & $20 \%$ \\
\hline
\end{tabular}

Dari data tersebut di atas dapat dicermati dan dianalisis bahwa harga jual batik sebelum didaftarkan Hak Cipta perpotong adalah sebesar Rp.200.000 menjadi Rp.250.000 , sehingga ada kenaikan sebesar Rp.50.000 atau naik sebesar $25 \%$. Sedangkan harga jual bordir sebelum didaftarkan Hak Cipta perpotong adalah sebesar Rp.400.000 menjadi Rp.600.000 , sehingga ada kenaikan sebesar Rp.200.000 atau naik sebesar 50\% . Di sisi lain harga jual tenun sebelum didaftarkan Hak Cipta perpotong adalah sebesar Rp.250.000 menjadi Rp.300.000 , sehingga ada kenaikan sebesar Rp.50.000 atau naik sebesar $20 \%$.

Kesimpulan sementara dengan didaftarkannya Hak Cipta batik, bordir dan tenun, maka terjadi kenaikan harga jual yang cukup signifikan. Fakta ini memberikan asumsi bahwa Konsumen batik , bordir dan tenun mampu menghargai karya cipta batik, bordir dan tenun dengan cara tetap mau membeli harga batik, bordir dan tenun dengan harga yang lebih tinggi . 
Tabel : 3 : Kenaikan Omzet Penjualan Dalam Kurun Waktu April 2018 - Mei 2019.

\begin{tabular}{|c|l|l|l|l|c|}
\hline Nomor & $\begin{array}{l}\text { Jenis } \\
\text { Pengrajin }\end{array}$ & $\begin{array}{l}\text { Omzet Penjualan / } \\
\text { Bulan Sebelum } \\
\text { Didaftarkan Hak } \\
\text { Cipta / Satu } \\
\text { Pengrajin }\end{array}$ & $\begin{array}{l}\text { Omzet Penjuala / } \\
\text { Bulan Setelah } \\
\text { Didaftarkan Hak } \\
\text { Cipta / Satu } \\
\text { Pengrajin }\end{array}$ & $\begin{array}{l}\text { Jumlah } \\
\text { Kenaikan } \\
\text { Per Bulan }\end{array}$ & $\begin{array}{c}\text { Prosentase } \\
\text { Kenaikan } \\
\text { Per Bulan }\end{array}$ \\
\hline 1. & Batik & \pm 600 potong & \pm 650 potong & 50 potong & $8,33 \%$ \\
\hline 2. & Bordir & \pm 300 potong & \pm 400 potong & 100 potong & $33,33 \%$ \\
\hline 3. & Tenun & \pm 900 potong & \pm 945 potong & 45 potong & $5 \%$ \\
\hline
\end{tabular}

membeli karya cipta batik, bordir dan

Dari data tersebut di atas dapat dicermati dan dianalisis bahwa omzet penjualan batik perbulan untuk setiap Pengrajin sebelum didaftarkan Hak Cipta adalah sebesar 600 potong, namun setelah didaftarkan Hak Cipta omzetnya naik menjadi menjadi 650 potong perbulan, sehingga ada kenaikan sebesar 50 potong atau naik sebesar $8,33 \%$. Sedangkan omzet penjualan bordir perbulan untuk setiap Pengrajin sebelum didaftarkan Hak Cipta adalah sebesar 300 potong, namun setelah didaftarkan Hak Cipta omzetnya naik menjadi menjadi 400 potong perbulan , sehingga ada kenaikan sebesar 100 potong atau naik sebesar 33,33\% . Di sisi lain omzet penjualan tenun perbulan untuk setiap Pengrajin sebelum didaftarkan Hak Cipta adalah sebesar 900 potong, namun setelah didaftarkan Hak Cipta omzetnya naik menjadi menjadi 945 potong perbulan, sehingga ada kenaikan sebesar 45 potong atau naik sebesar 5\% . Kesimpulan sementara dengan didaftarkannya Hak Cipta batik , bordir dan tenun, hanya terjadi kenaikan omzet penjualan yang kurang signifikan . Fakta ini memberikan asumsi bahwa Konsumen batik, bordir dan tenun secara luas kurang mampu menghargai karya cipta batik , bordir dan tenun atau kurang berminat tenun , terbukti dengan sedikitnya kenaikan omzet penjualan .

3. Strategi untuk menembus pemasaran global untuk produk Pengrajin di sektor batik, bordir dan tenun yang sudah memilik Hak Cipta :

Strategi menembus pemasaran global untuk produk Pengrajin di sektor batik , bordir dan tenun yang sudah memiliki Hak Cipta adalah dengan difasilitasinya Para Pengrajin ikut pameran produk batik, bordir dan tenun baik di tingkat lokal, nasional dan internasional .

Pameran pemasaran produk secara langsung mampu meningkatkan omzet penjualan sekaligus memperluas pasar . Tim Peneliti dengan adanya dana hibah yang sangat terbatas jumlahnya hanya mampu memfasilitasi pameran produk batik, bordir dan tenun, masing masing satu orang Pengrajin untuk pameran produk tingkat internasional .

Namun agar Para Pengrajin batik, bordir dan tenun dapat dibantu untuk memasarkan produknya di tingkat pemasaran global, maka Peneliti bersama Tim memfasilitasi dengan membuatkan Web Site pemasaran produk bersama. Pemasaran produk bersama ini , diperuntukan bagi seluruh Pengrajin yang sudah tergabung menjadi 
Anggota Koperasi batik, bordir dan tenun .

Selain itu secara individu Para Pengrajin batik, bordir dan tenun difasilitasi oleh Peneliti bersama Tim, untuk membuat akun face book maupun instagram dilanjutkan dengan memamerkan produknya baik secara individu maupun gabungan, melalui up load produk di media sosial baik face book maupun instagram .

Hasil kenaikan omzet penjualan dengan melalui cara on line baik dengan menggunakan alamat web site , akun face book dan akun instagram , memang tidak secara langsung dan serta merta menaikkan omzet penjualan . Para Pengrajin batik, bordir dan tenun harus bersabar dan tetap tekun serta konsisten untuk terus memamerkan produknya melalui sistem on line, agar diketahui oleh konsumen pasar global. Butuh waktu yang cukup untuk suatu produk dapat merebut hati konsumen . Konsumen harus tertarik lebih dahulu dan kemudian memiliki minat untuk membeli dan selanjutnya Konsumen harus dibuat percaya supaya dan puas supaya akhirnya menjadi Pelanggan loyal. Pelanggan yang loyal secara tidak langsung akan dapat menjadi Marketing pemasaran yang gratis untuk Para Pengrajin batik , bordir dan tenun .

Pemasaran produk secara on line akan menjamin keberlangsungan usaha Para Pengrajin, karena akan ada peluang yang besar untuk menjaring Konsumen secara terus - menerus di seluruh dunia . Keuntungan lain yang didapat dari pemasaran produk secara on line adalah biaya penjualan produk lebih murah karena tidak perlu menyediakan tempat usaha / toko untuk pemasaran produk . Biaya pemasaran yang lebih murah akan menaikkan margin keuntungan yang lebih tinggi .

Kesimpulan sementara yang dapat ditarik adalah bahwa pemasaran global produk Para Pengrajin batik, bordir dan tenun, melalui sistem on line akan menghemat biaya pemasaran dan memperluas pangsa pasar, dengan demikian akan berpotensi menaikkan omzet penjualan dan menaikkan margin keuntungan .

G. Kesimpulan :

1. Cara meningkatkan daya saing Pengrajin batik, bordir dan tenun adalah dengan mendaftarkan Hak Cipta atas karyanya . Kendala akan keterbatasan sumber daya manusia dan kemampuan finansial dari Para Pengrajin, maka Peneliti bersama Tim melakukan pendampingan dan memberikan fasilitasi untuk mendaftarkan Hak Cipta atas karya ciptanya .

2. Strategi untuk menaikkan omzet penjualan dan menaikkan harga jual, terhadap produk Pengrajin di sektor batik, bordir dan tenun, yang sudah memiliki Hak Cipta, dilakukan dengan cara sosialisasi, penyuluhan dan pendidikan kepada Konsumen agar memahami seluk - beluk tentang Hak Cipta . Setelah Konsumen memahami tentang Hak Cipta , diharapkan Konsumen mampu memiliki sikap nyata berupa kebanggaan dan tingkah laku riil untuk membeli produk batik, bordir dan tenun yang telah didaftarkan Hak Ciptanya dengan harga yang agak 
tinggi dan tetap mau membeli dalam jumlah yang banyak .

3. Strategi untuk menembus pemasaran global untuk produk Pengrajin di sektor batik, bordir dan tenun yang sudah memilik Hak Cipta, adalah dengan memfasilitasi Para Pengrajin untuk ikut melakukan pameran penjualan produk secara langsung di forum internasional. Selain itu juga memasilitasi untuk memamerkan dan menjual produk melalui on line . Pemasaran on line ini dilakukan melalui web site, face book dan instagram . Media pemasaran secara on line ini bisa menghemat biaya pemasaran, dengan demikian Para Pengrajin akan memperoleh minimal dua manfaat penting yaitu pertama dapat memperluas pasar penjualan ditingkat global / internasional, yang kedua dapat meningkatkan omzet penjualan , sehingga margin keuntungan menjadi lebih banyak .

\section{DAFTAR PUSTAKA :}

\section{Buku - Buku :}

Abdullah, P., Alisjahbana, Armida, S., Effendi, N., Boediono, 2002. Daya Saing Daerah, Konsep dan Pengukurannya di Indonesia, Edisi 1, BPFE, Yogyakarta

Batik Kudus: Semangat Multikulturalisme Dalam Selembar Kain | Horizon Budaya [online], 2017. Available from:

https://denmasdeni.blogspot.co.id/201 6/01/batik-kudus-semangatmultikulturalisme.html [Accessed 2 Jan 2017]

Becattini, G., 1990, The Marshallian Industrial District as a Socioeconomic Notion. In F. Pyke, G. Becattini \& W. Sengenberger (Eds.), Industrial
Districts and Inter-Firm Cooperation in Italy. Geneva: ILO.

Budi Santoso, 2009, Pengantar HKI Dan Audit HKI Untuk Perusahaan, Semarang : Penerbit Pustaka Magister, Semarang.

Desrochers dan Sautet. 2004. Cluster Based Economic Strategy, Fasilitation Policy and The Market Process, The Review og Austrian Economics, Vol. 17. P. 233 - 245.

Gould, David M. and Gruben, William C. (1996), "The Role of Intellectual Property Rights in Economic Growth,"dalam artikel Purwanto

H.OK Saidin, 2004, Aspek Hukum Kekayaan Intelektual, PT.Raja Grafindo Persada, Jakarta.

Hadi Setia Tunggal, 2011, Pokok-pokok Hukum Hak Kekayaan Intelektual (HKI/HaKI), Harvarindo,Jakarta.

Hayter, Roger, 1997, The Dynamic of Industrial Location:The Factory, the Firm, and the Production System. Chichester: John Wiley \& Sons.

Hill, H., 2001, Small and Medium Enterprises inIndonesia: Old Policy Challenges for a New Administration. Asian Survey, 41(2): 248-70. Isard, Walter, 1956, Location and Space Economy. Cambridge: MIT Press.

Iswi Hariyani, 2010, Prosedur Mengurus HAKI yang Benar, Pustaka Yustisia, Yogyakarta.

Kanwar, S.and Evenson, R. E. (2003), "Does Intellectual Property Right Protection Spur Technological Change. Oxford Economic Papers,

Kuncoro, M., 2002, Analisis Spasial dan Regional: Studi Aglomerasi dan Kluster Industri Indonesia. Yogyakarta: UPP-AMP YKPN.

Lexy J Moleong, 2006, Metodelogi Penelitian Kualitatif, PT Remaja Rosdakarya, Bandung.

Nindyo Pramono, 2006, Bunga Rampai Hukum Bisnis Aktual, PT Citra Aditya Bakti, Bandung.

Porter, M. E., 1998, Clusters and the New Economics of Competition. Harvard 
Business Review, NovemberDecember(6), 77-91

Ritonga SAW. Analisis Determinan Daya Saing Ekonomi Kabupaten Batu Bara. 2015;

Ronny Hanitijo Soemitro, 1983, Metodologi Penelitian Hukum dan Jurimetri, Ghalia Indonesia, Jakarta.

Rosenfeld. 1995. Labour Market Implication of Scale, Innovation, and Entrepreneurship. Washington DC. US Commision on Immigration Reform's Maxico-US Binational Migration Study.

Soedaryo Soimin, 1995, Kitab UndangUndang Hukum Perdata, Pradya Paramita, Jakarta.

Soekesi, Agustine Eva Maria. 2013. Karakteristik UKM Batik Pada Klaster Batik Di Jawa Tengah. Seri Kajian Ilmiah,Vol. 15.No.1 Januari 2013. LPPM.Unika Soegijapranata

Sudargo Gautama, 1976, Arbitrase Dagang Internasional, Alumni Bandung.

Sudaryanto dan Hanim,Anifatul. 2002. Evaluasi kesiapan UKM Menyongsong Pasar Bebas Asean (AFTA) : Analisis Perspektif dan Tinjauan Teoritis. Jurnal Ekonomi Akuntansi dan Manajemen, Vol 1 No 2, Desember 2002.

Sudaryanto R, Wijayanti RR. Strategi pemberdayaan UMKM menghadapi pasar bebas Asean. Pus. Kebijak. Ekon. Makro Badan Kebijak. Fiskal Kementeri. Keuang. Jkt. 2013;

Sunaryanto, L.T. dan M Tambunan, 2004, Industri Skala Menengah: Potensi dan Peluang Pengembangannya, Dian Ekonomi, Fakultas Ekonomi UKSW,

Susilo Martoyo. 1998. Manajemen Sumber Daya Manusia. Yogyakarta. BPFE.

T Purwanto, 2011, Intellectual Property Rights, Innovation, and Economic Growth in Sub-Saharan Africa (Institut Pertanian Bogor.)

Tahwin, Muhammad. Ahmad Aviv, M. 2013. Mengukur Probabilitas Industri Batik Tulis Lasem Berorientasi
Ekspor. Fokus Ekonomi. Vol 8. No. 2. STIE Pelita Nusantara

Tambunan, T., 1999, Perkembangan Industri Skala Kecil Di Indonesia. Jakarta: PT. Mutiara Sumber Widya

\section{Peraturan Perundang - Undangan :} Undang - Undang Nomor : 28 Tahun 2014 Tentang Hak Cipta 
